\title{
Size-fractionated phytoplankton diversity in the NW Iberian coast: a combination of microscopic, pigment and molecular analyses
}

\author{
Fabrice Not ${ }^{1,4}$, Manuel Zapata ${ }^{2}$, Yolanda Pazos $^{3}$, Emilia Campaña ${ }^{2}$, Marylo Doval ${ }^{3}$, \\ Francisco Rodríguez ${ }^{1,5, *}$
}

\begin{abstract}
${ }^{1}$ Station Biologique de Roscoff, UMR 7144 CNRS et Université Pierre et Marie Curie, BP 74, 29682 Roscoff Cedex, France
${ }^{2}$ Centro de Investigacións Mariñas, Xunta de Galicia, Apdo. 13, 36620 Vilanova de Arousa, Spain

${ }^{3}$ Instituto Tecnolóxico para o Control do Medio Mariño de Galicia (INTECMAR), Xunta de Galicia, Peirao de Vilaxoan, 36611 Villagarcía de Arosa, Spain
\end{abstract}

${ }^{4}$ Present address: Institut de Ciències del Mar (CMIMA-CSIC), Passeig Marítim de la Barceloneta 37-49, 08003 Barcelona, Spain

${ }^{5}$ Present address: Centro Oceanográfico de Canarias (IEO), Ctra. San Andrés 45, 38180 S/C Tenerife, Spain

\begin{abstract}
The aim of our study was to describe the diversity and dynamics of size-fractionated phytoplankton at a fixed station (P2, Ría de Pontevedra, NW Spain) from late spring to early winter. Phytoplankton successions were assessed weekly from May to November 2004 using pigment analyses, light microscopy and fluorescence in situ hybridization coupled with tyramide signal amplification (FISH-TSA). Periodic upwelling events triggered the development of diatom populations followed by periods of relaxation/downwelling conditions where remineralization processes (maxima of $\mathrm{NH}_{4}^{+}$), raised temperatures and/or low salinity waters from rainfall favored the increase of picophytoplankton. Marked differences were observed between diversity and dynamics of the micronano $(>3 \mu \mathrm{m})$ and pico $(<3 \mu \mathrm{m})$ size fractions. Micro-nanoplankton organisms contributed $85 \%$ of chl a on average (range, 55 to $99 \%$ ); diatoms and cryptophytes were the dominant pigment groups $(\sim 70 \% \mathrm{chl} \mathrm{a}$ in this size category). In the picoplankton, chlorophytes and non-chlorophytes contributed to an identical proportion $(50 \%)$ of total picoeukaryotes determined by FISH-TSA. A large fraction of these $(\sim 65 \%)$ could be accounted for by group-specific probes. Molecular data suggested that chl $b$-containing picoplankton were mostly accounted for by prasinophyceans belonging to the order Mamiellales (55\% of total chlorophyte cells), with Micromonas pusilla as its major component ( $70 \%$ of Mamiellales, $\sim 20 \%$ of all picoeukaryotes), similar to that found in other temperate coastal locations. In contrast, HPLC analyses severely underestimated the contribution of prasinophyceans and indicated $<10 \%$ Mamiellales among chlorophytes. Among chromophytes, the haptophyte probe targeted $\sim 25 \%$ of non-chlorophyte cells, and pelagophyceans were sporadically abundant (13\% nonchlorophyte cells, May to September). After pigment analyses the main chromophytes were diatom II (chl $c_{3}$-containing), pelagophyceans and haptophytes with 20,13 and $8 \%$ of picoplanktonic chl $a_{\text {, }}$ respectively.
\end{abstract}

KEY WORDS: Phytoplankton diversity · Pigments · FISH-TSA · Microscopy • Picoplankton • Ría de Pontevedra

Resale or republication not permitted without written consent of the publisher

\section{INTRODUCTION}

The NW Iberian Rías are highly productive coastal embayments influenced by seasonal upwelling episodes due to the prevailing northerly winds from April to October (Doval et al. 1998). These upwelling conditions are interspersed with stratification due to wind relaxation and downwelling when the wind regime shifts to southerlies. Phytoplankton blooms in the rías are triggered by upwellings from spring to fall, gener- 
ally composed of large organisms (>20 $\mu \mathrm{m}$, mainly diatoms) which represent $\sim 60 \%$ of primary productivity year round (Tilstone et al. 2003). In comparison, changes in the primary production on the adjacent shelf waters are less pronounced and piconanoplankton $(<20 \mu \mathrm{m})$ usually dominates the biomass (Lorenzo et al. 2005, Rodríguez et al. 2006).

The seasonal cycle and ecology of nano- and microphytoplankton in the rías have been well characterized (Varela 1992). Their populations follow the typical species succession usually observed at temperate latitudes, superimposed by smaller cycles linked to the entrainment of oceanic water masses during upwelling and relaxation episodes (Figueiras \& Niell 1987). However, unlike other temperate coastal areas, the maximum of biomass in the rías is usually reached in summer (Varela 1992).

Much less is known about the smallest eukaryotes, although pico-nanoplankton cells were estimated to contribute up to $50 \%$ of total primary production in defined periods (Figueiras et al. 2002). Pigment analysis suggested a rather unusual picoplankton composition at Stn P2, Ría de Pontevedra (Rodríguez et al. 2003). First, although chl $b$-containing algae appeared as the major chemotaxonomic group ( $>60 \%$ picoplanktonic chl a), the dominant accessory carotenoid was fucoxanthin, the traditional chemotaxonomic marker for diatoms (Rodríguez et al. 2003). Divinyl chl $a$, the exclusive marker for the cyanobacterium Prochlorococcus, occurred periodically in shelf waters but never inside the rías (Rodríguez et al. 2003, 2006).

Another surprising feature of the picoplankton communities of the Ría de Pontevedra suggested by the pigment surveys was that prasinophyceans typically represented $<20 \%$ of chl a from chlorophytes, the latter remaining as a 'black box' of chl $b$-containing organisms (Rodríguez et al. 2003, 2006). In contrast, molecular studies of picoplankton in 2 coastal areas of the North Atlantic (English Channel; Biégala et al. 2003, Not et al. 2004) established the dominance of prasinophyceans, specifically Micromonas pusilla, on the whole picophytoplankton community.

We re-investigated the picoplankton community in the Ría de Pontevedra with the goal of verifying whether or not these unusual features in fact characterize the picoplankton community of this ría, and, more generally, to compare how the picoplankton versus larger nano- and microplankton communities respond dynamically to environmental forcing. Diversity studies with emphasis on the smallest eukaryotic groups benefited recently from the inter-comparisons of results obtained by HPLC pigment analyses and molecular procedures (Wawrik et al. 2003, Not et al. 2004, Fuller et al. 2006). These approaches provided a comprehensive reconstruction of phytoplank- ton assemblages, and suggested that many of the taxonomic groups encountered either a lack, or have a limited number, of cultured strains. In the present study, HPLC pigment analysis, light microscopy and fluorescence in situ hybridization coupled with tyramide signal amplification (FISH-TSA) were combined to describe the diversity and dynamics of size-fractionated phytoplankton at a fixed station (P2, Ría de Pontevedra, NW Spain) from late spring to early winter.

\section{MATERIALS AND METHODS}

Study site and sampling procedures. A single sampling station located in the NW Iberian Peninsula, (StnP2, Ría de Pontevedra, $42^{\circ} 21.40^{\prime} \mathrm{N}, 8^{\circ} 46.42^{\prime} \mathrm{W}$, $27 \mathrm{~m}$ depth; Fig.1) was sampled weekly over a 6 mo period (May to November 2004) as part of the Galician harmful algal bloom (HAB) monitoring program conducted by INTECMAR (Mariño et al. 1998), on board RV 'Jose María Navaz'. A CTD profiler (Sealogger, CTD Sea Bird 25) was employed to obtain conductivity and temperature data. Seawater samples were collected from the water column using a PVC hose (Lindahl 1986) divided into 3 sections: $0-5,5-10$ and $10-15 \mathrm{~m}$. An integrated

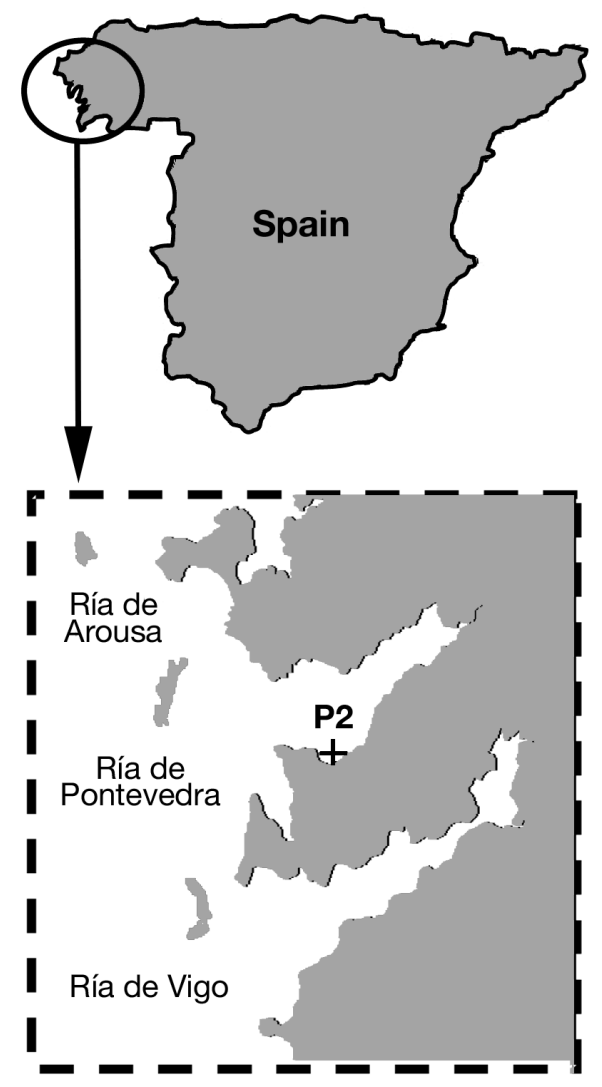

Fig. 1. Location of sampling site (Stn P2), Ría de Pontevedra, NW Iberian Peninsula, Spain 
water sample (0 to $15 \mathrm{~m}$ depth) was obtained by mixing equal volumes from each hose section for further phytoplankton cell counts, HPLC and FISH-TSA analyses. Nutrient analysis were made with a Traacs 800-2000 segmented flow analysis (SFA) system.

Identification of micro- and nanoplankton. Samples were preserved in Lugol's iodine solution and sedimented in Utermöhl's chambers (25 ml). Microplankton to small nanoplankton cells were counted using an inverted microscope (Nikon Diaphot TMD; Utermöhl 1958) and identified to species level when possible. The whole bottom of the chamber was examined at $10 \times, 20 \times$ and $40 \times$ magnification.

HPLC pigment analysis. Seawater samples (1.5 l) obtained from the integrated profile (0 to $15 \mathrm{~m}$ ) were filtered through $47 \mathrm{~mm}$ diameter Whatman GF/D and $\mathrm{GF} / \mathrm{F}$ filters (vacuum pressure $<75 \mathrm{~mm} \mathrm{Hg}$ ) and filters were stored at $-20^{\circ} \mathrm{C}$ until analysis. Phytoplankton passing through a GF/D (2.7 $\mu \mathrm{m}$ nominal pore size) but retained onto GF/F filters ( $0.7 \mu \mathrm{m}$ nominal pore size) was considered to represent the picoplankton fraction. Frozen filters were extracted in variable volumes ( 3 to $6 \mathrm{ml}$ ) of $95 \%$ methanol using a spatula for filter grinding and further sonicated for $5 \mathrm{~min}$ at low temperature $\left(\sim 5^{\circ} \mathrm{C}\right)$. Extracts were then filtered through Whatman GF/F filters to remove cell and filter debris. An aliquot $(1 \mathrm{ml})$ of the methanol extract was mixed with $0.2 \mathrm{ml}$ of Milli-Q-purified water to avoid peak distortion (Zapata \& Garrido 1991). A volume of $200 \mu \mathrm{l}$ was injected immediately after the water addition to avoid loss of pigments (Latasa et al. 2001). Pigment separation and analysis was performed by HPLC according to Zapata et al. (2000). HPLC equipment was a Waters Alliance System consisting of a 2695 separations module and a 996 photodiode array detector interfaced with a 474 scanning fluorescence detector by a Sat/in analog interface. Pigments were identified by co-chromatography with authentic standards and by diode-array spectroscopy (wavelength range: 350 to $750 \mathrm{~nm}$, $1.2 \mathrm{~nm}$ spectral resolution). Chlorophylls were also detected by fluorescence at $440 \mathrm{~nm}$ excitation and $650 \mathrm{~nm}$ emission wavelengths. Pigments were quantified using external standards and extinction coefficients compiled by Jeffrey et al. (1997).

CHEMTAX analysis. HPLC pigment data of each size-fraction were processed by means of a chemical taxonomy program (CHEMTAX, Mackey et al. 1996). Nine micro-nanoplankton and 8 picoplankton pigment groups were defined in the CHEMTAX input matrix (Table 1). Individual marker pigments are not always specific to a single pigment group and could be shared by different taxonomic classes. For further details these pigment groups were defined following the pigment composition and high-light pigment ratios normalized to chl a by Rodríguez et al. (2006).
FISH-TSA analysis and epifluorescence microscopy. Whole-cell FISH allows the detection and enumeration of particular taxa targeted by specific oligonucleotide probes. For photosynthetic picoeukaryotes, an additional step of fluorescent signal amplification is required, using TSA. The relevance of the results obtained by FISH on natural communities depends mainly on the set of probes available. Nevertheless, this is the only method offering the possibility to estimate cell abundance and directly visualize picoeukaryotic cells under epifluorescence microscopy. Seawater samples $(90 \mathrm{ml})$ were prefiltered through a $3 \mu \mathrm{m}$ pore size Nuclepore filter and fixed for $1 \mathrm{~h}$ at $4^{\circ} \mathrm{C}$ with $10 \mathrm{ml}$ of $10 \%$ paraformaldehyde. Samples were then filtered onto $0.2 \mu \mathrm{m}$ Whatman Anodisc filters with vacuum pressure kept below $75 \mathrm{~mm}$ $\mathrm{Hg}$. Filters were subsequently dehydrated in an ethanol series $(50 \%, 80 \%, 100 \%, 3$ min each) and stored at $-80^{\circ} \mathrm{C}$ until further analysis. Oligonucleotide probes with a $5^{\prime}$ aminolink (C6; MWG-Biotech AG) were labeled with horseradish peroxidase (HRP) according to Urdea et al. (1988) and Amann et al. (1992). The oligonucleotide probes EUK1209R, CHLO01 and NCHLO01 were used as a mix in order to target all picoeukaryotes, CHLO02 for chlorophytes, NCHLO01 for non-chlorophytes, PRYM02 for haptophytes, CRYPTO13 for cryptophytes, PRAS04 for Mamiellales, OSTREO01 for Ostreococcus sp., BATHY01 for Bathycoccus sp., MICRO01 for Micromonas sp. and PELA01 for pelagophyceans (Giovannoni et al. 1988, Simon et al. 1995, 2000, Not et al. 2004, F. Not et al. unpubl.). More details on the FISH-TSA probes can be found at www.sb-roscoff.fr/Phyto/Databases/RNA_probes_introduction.php. Taxon-specific detection of cells collected on filters was achieved by hybridizations with the various HRP-labeled probes listed above. After amplification of the fluorescent signal, hybridized cells were counted under epifluorescence microscopy (for further methodological details see Not et al. 2002).

\section{RESULTS}

\section{Hydrographic data}

Annual hydrographic conditions at Stn P2 (Fig. 2) were similar to those previously reported (Rodríguez et al. 2003). Successive upwelling-relaxation cycles were observed from May to mid-October and downwelling and thermal homogenization from the end of October to December (Fig. 2A). Averaged data from the upper $15 \mathrm{~m}$ water column (Fig. 2B) revealed 3 minima of salinity in August, October and November, coinciding with strong downwelling events. Temperature varied from $13^{\circ} \mathrm{C}$ in May and November, up to $20^{\circ} \mathrm{C}$ in August. Nitrate and phosphate (Fig. 2C) replenish- 
Table 1. Input ratio matrix and output pigment ratios (within parentheses if modified after CHEMTAX analyses) in (A) micronanoplankton and (B) picoplankton fractions. chl $C_{2}$-Ehux: chl $C_{2}$-MGDG [14:0/18:4]); chl $C_{2}$-Chry: chl $C_{2}$-MGDG [14:0/14:0]); Allo: alloxanthin; 19 buta: 19'-butanoyloxyfucoxanthin; Fuco: fucoxanthin; 19 hex: 19'-hexanoyloxyfucoxanthin; Per: peridinin; Pras: prasinoxanthin; Uriol: uriolide; Zea: zeaxanthin

\begin{tabular}{|c|c|c|c|c|c|c|c|c|c|c|c|c|}
\hline $\begin{array}{l}\text { Pigment group } \\
\text { (A) }\end{array}$ & $\operatorname{chl} C_{3}$ & $\operatorname{chl} C_{2}$ & $\operatorname{chl} C_{1}$ & $\begin{array}{l}\text { chl } C_{2}^{-} \\
\text {Ehux }\end{array}$ & $\begin{array}{c}\text { chl } C_{2}- \\
\text { Chry }\end{array}$ & Per & 19 buta & Fuco & Pras & 19 hex & Allo & $\operatorname{chl} b$ \\
\hline Diatom I & - & $\begin{array}{c}0.165 \\
(0.208)\end{array}$ & $\begin{array}{c}0.111 \\
(0.196)\end{array}$ & - & - & - & - & $\begin{array}{c}0.546 \\
(0.687)\end{array}$ & - & - & - & - \\
\hline Diatom II & $\begin{array}{c}0.116 \\
(0.114)\end{array}$ & $\begin{array}{c}0,299 \\
(0.455)\end{array}$ & - & - & - & - & - & $\begin{array}{c}0.777 \\
(0.395)\end{array}$ & - & - & - & - \\
\hline Haptophyte I & $\begin{array}{c}0.221 \\
(0.332)\end{array}$ & 0.171 & - & 0.097 & - & - & - & 0.722 & - & 0.236 & - & - \\
\hline Haptophyte II & 0.151 & 0.139 & - & - & $\begin{array}{c}0.125 \\
(0.100)\end{array}$ & - & 0.008 & 0.121 & - & 0.811 & - & - \\
\hline Chlorophyte & - & - & - & - & - & - & - & - & - & - & - & $\begin{array}{c}0.433 \\
(0.782)\end{array}$ \\
\hline Prasinophycean & - & - & - & - & - & - & - & - & 0.322 & - & - & 0.790 \\
\hline Pelagophycean & 0.153 & 0.316 & - & - & - & - & 0.240 & $\begin{array}{c}1.241 \\
(0.124)\end{array}$ & - & - & - & - \\
\hline Dinophyte & - & 0.111 & - & - & - & - & - & - & - & - & - & - \\
\hline Cryptophyte & - & $\begin{array}{c}0.060 \\
(0.093)\end{array}$ & - & - & - & 0.442 & - & - & - & - & $\begin{array}{c}0.172 \\
(0.266)\end{array}$ & - \\
\hline $\begin{array}{l}\text { Pigment group } \\
\text { (B) }\end{array}$ & $\operatorname{chl} c_{3}$ & $\operatorname{chl} c_{2}$ & Uriol & 19 buta & Fuco & Pras & 19 hex & Allo & Zea & $\operatorname{chl} b$ & & \\
\hline Diatom II & $\begin{array}{c}0.076 \\
(0.127)\end{array}$ & $\begin{array}{c}0.299 \\
(0.337)\end{array}$ & - & - & $\begin{array}{c}1.143 \\
(0.528)\end{array}$ & - & - & - & - & - & & \\
\hline Haptophyte & $\begin{array}{c}0.091 \\
(0.151)\end{array}$ & 0.139 & - & 0.008 & 0.073 & - & $\begin{array}{c}0.853 \\
(0.685)\end{array}$ & - & - & - & & \\
\hline Chlorophyte & - & - & - & - & - & - & - & - & - & $\begin{array}{c}0.319 \\
(0.936)\end{array}$ & & \\
\hline Prasinophycean & - & - & - & - & - & 0.439 & - & - & - & 0.568 & & \\
\hline Mamiellales & - & - & $\begin{array}{c}0.143 \\
(0.197)\end{array}$ & - & - & $\begin{array}{c}0.171 \\
(0.313)\end{array}$ & - & - & - & 0.523 & & \\
\hline Pelagophycean & $\begin{array}{c}0.09 \\
(0.315)\end{array}$ & $\begin{array}{c}0.308 \\
(0.445)\end{array}$ & & $\begin{array}{c}0.151 \\
(0.274)\end{array}$ & $\begin{array}{c}0.317 \\
(0.373)\end{array}$ & & - & - & - & - & & \\
\hline Cryptophyte & - & 0.060 & & & & & - & 0.339 & - & - & & \\
\hline Synechococcus & - & - & - & - & - & - & - & - & 0.939 & - & & \\
\hline
\end{tabular}

ment in the upper $15 \mathrm{~m}$ was mediated by strong upwelling pulses or episodic runoff events. However, they were quickly consumed during the summer and reached maximum values $\left(11 \mathrm{\mu M} \mathrm{l}^{-1} \mathrm{NO}_{3}{ }^{-}\right.$and $1 \mu \mathrm{M} \mathrm{I}^{-1}$ $\mathrm{PO}_{4}{ }^{3-}$ ) during the upwelling pulse in mid-September. Peaks of ammonium were detected in late August, mid-September and October, reaching a maximum of $2.4 \mu \mathrm{M} \mathrm{l}^{-1} \mathrm{NH}_{4}{ }^{+}$on 13 October, due to the higher remineralization processes.

\section{Micro-nanoplankton composition}

Diatoms (e.g. Chaetoceros socialis, Leptocylindrus danicus, Pseudonitzschia delicatissima, Rhizosolenia fragile and Thalassiosira spp.), unidentified flagellates, and dinoflagellates (e.g. Amphidinium flagellans, Ceratium pelagicum and Prorocentrum micans) were the most abundant protistan taxa enumerated by microscopy (Fig. 3A,B). The absolute maximum of diatoms at the beginning of the sampling period $(4.2 \times$ $10^{6}$ cells $\mathrm{l}^{-1}$ ) was due to L. danicus, and Dinophysis sp. was responsible for the maximum of dinoflagellates in July $\left(3.5 \times 10^{4}\right.$ cells $\left.\mathrm{l}^{-1}\right)$. Other groups were secondary and represented by a limited set of species, such as haptophytes, which were only represented by Phaeocystis spp. (Fig. 3B), silicoflagellates (Distephanus speculum, Dictyocha fibula) and raphidophytes (Heterosigma akashiwo). The temporal distribution of haptophytes showed 2 principal maxima in September and November, but these were irrelevant in terms of pigment contribution. 


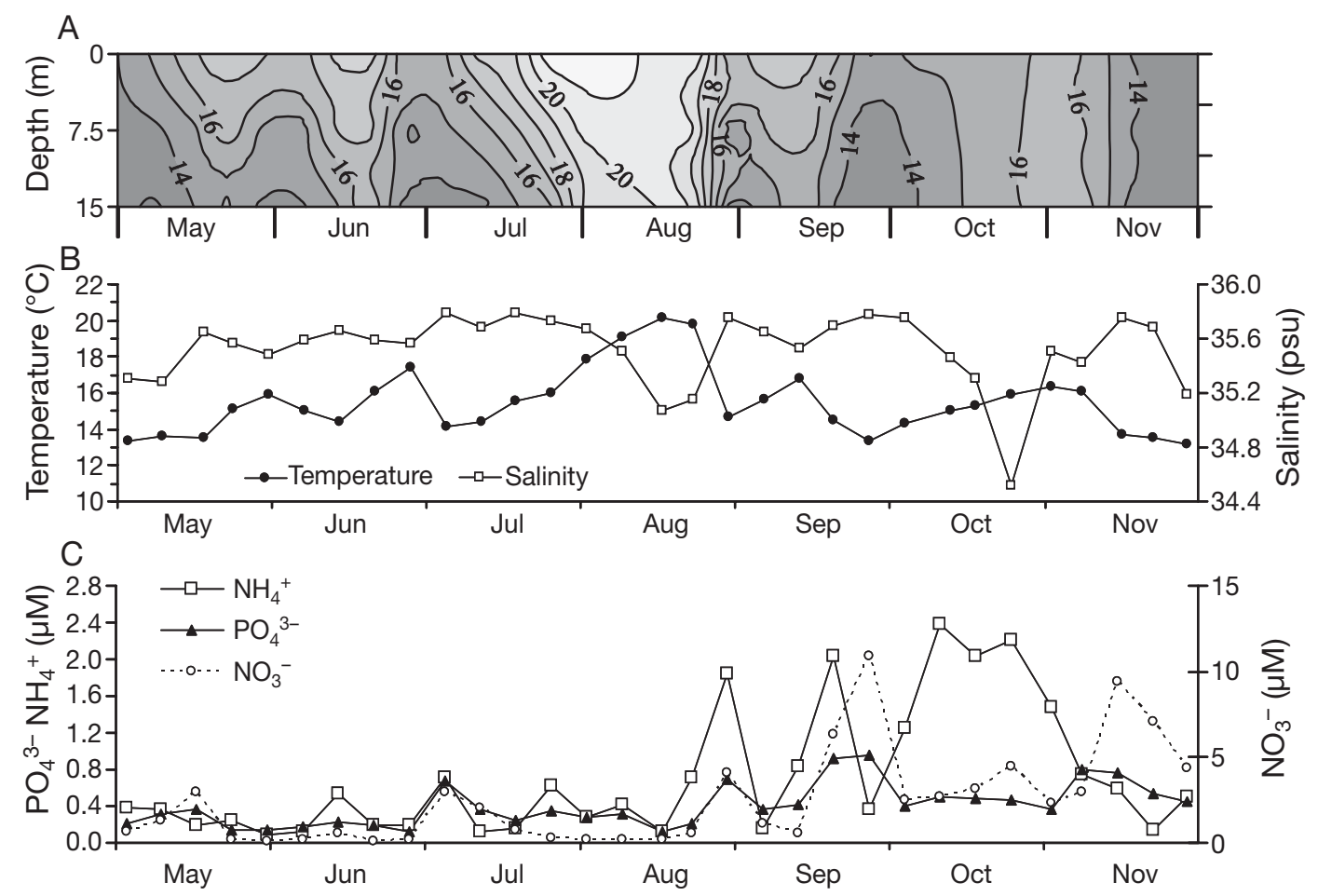

Fig. 2. (A) Vertical distribution of temperature, (B) average temperature and salinity, and (C) nutrients, at 0 to $15 \mathrm{~m}$ depth range in May to November 2004

Total chl a concentration ranged from 0.25 to $6.5 \mu \mathrm{g}$ $\mathrm{l}^{-1}$ during the study (Fig. 3C). From size-fractionated pigment analyses, micro-nanoplankton organisms contributed to an average of $85 \%$ total chl a (range, 55 to $99 \%$; Fig. 3C). According to pigment analyses, diatoms, cryptophytes (not distinguished by microscopy) and haptophytes accounted for $\sim 90 \%$ of total chl $a$ in this size fraction (Fig. 3D).

Diatom II (containing chl $c_{3}$ ) and cryptophytes were the main contributors to micro-nanoplanktonic chl a (mean $\pm \mathrm{SD}, 39 \pm 15$ and $18 \pm 15 \%$ chl $a$, respectively), with diatom I, haptophytes and dinoflagellates being secondary groups $(14 \pm 15,12 \pm 11$ and $7 \pm 7 \% \mathrm{chl} a$, respectively). A shift in the pigment signature of micro-nanoplankton was evidenced following the succession of upwelling, relaxation and downwelling conditions from May to November (Fig. 3D). Thus, a diatom-based population during the main upwelling pulses in May, July and September was substituted by flagellates, principally cryptophytes and haptophytes, in June, July-August and October during relaxation and downwelling conditions (Fig. 2A). These hydrographic events were also characterized by changes in nutrients as shown by the $\mathrm{NH}_{4}{ }^{+}$maxima in summer and October before water column homogenization. These maxima of $\mathrm{NH}_{4}{ }^{+}$(Fig. 2C) coincided with the annual maxima of peridinin-containing dinoflagellates in September and October, after the last upwelling pulse (due to the cryptophyte plastids in Dinophysis sp., the maximum abundance of Dinophysis sp. in July cannot be distinguished from cryptophytes in pigment analysis). Positive correlations with $\mathrm{NH}_{4}{ }^{+}$were found for both dinoflagellate $\left(p<0.010 ; r^{2}=0.50 ; n=29\right)$ and cryptophyte pigment groups $\left(\mathrm{p}<0.05 ; \mathrm{r}^{2}=0.39 ; \mathrm{n}=29\right)$. In contrast, negative relationships with $\mathrm{NH}_{4}{ }^{+}$were found for both total diatom cell numbers determined by microscopy ( $<<0.05 ; \mathrm{r}^{2}=-0.38 ; \mathrm{n}=29$ ) and the diatom II pigment group $\left(\mathrm{p}<0.05 ; \mathrm{r}^{2}=-0.43 ; \mathrm{n}=29\right)$. The diatom I pigment group exhibited a negative relationship with temperature $\left(\mathrm{p}<0.05 ; \mathrm{r}^{2}=-0.37 ; \mathrm{n}=29\right)$, whereas both haptophyte pigment groups I and II showed positive correlations with temperature $(\mathrm{p}<$ $0.05 ; \mathrm{r}^{2}=0.43 ; \mathrm{n}=29$, and $\mathrm{p}<0.001 ; \mathrm{r}^{2}=0.72 ; \mathrm{n}=29$, respectively). Finally, chlorophytes were a minor component of micro-nanoplankton but sporadically important in summer and autumn, matching the lowest contribution of micro-nanoplankton to total chl $a$ (Fig. 3C,D).

\section{Picoplankton composition}

During the period studied, chlorophytes and nonchlorophytes each represented on average $50 \pm 25 \%$ (mean $\pm \mathrm{SD}$ ) of total picoeukaryote cell numbers assessed by FISH-TSA (Fig. 4A,B). Overall, a large fraction of picoeukaryotes ( $65 \%$ on average) were accounted for by the group-specific probes used in 
(A)

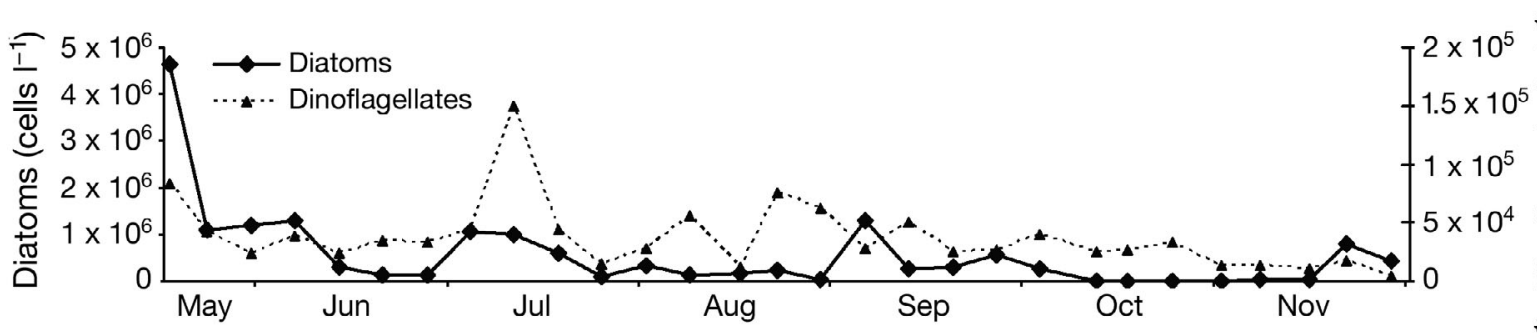

(B)

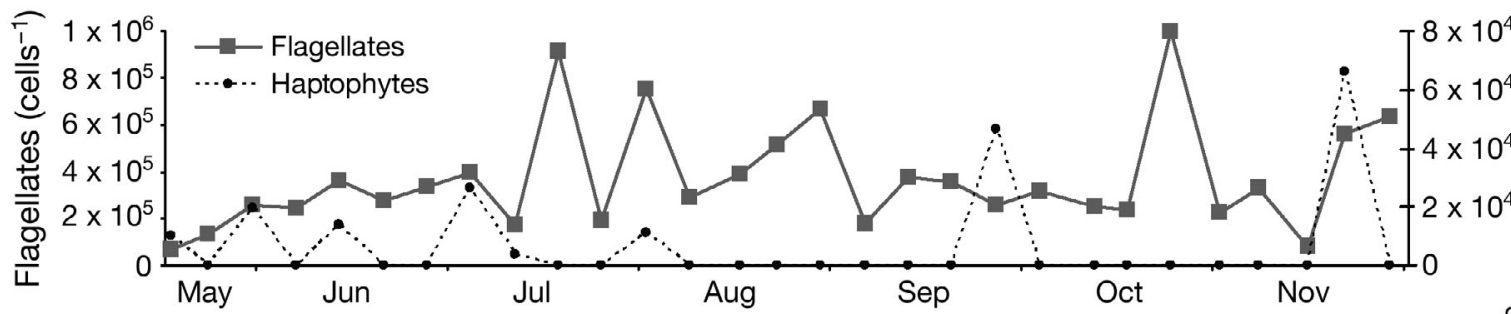

(C)
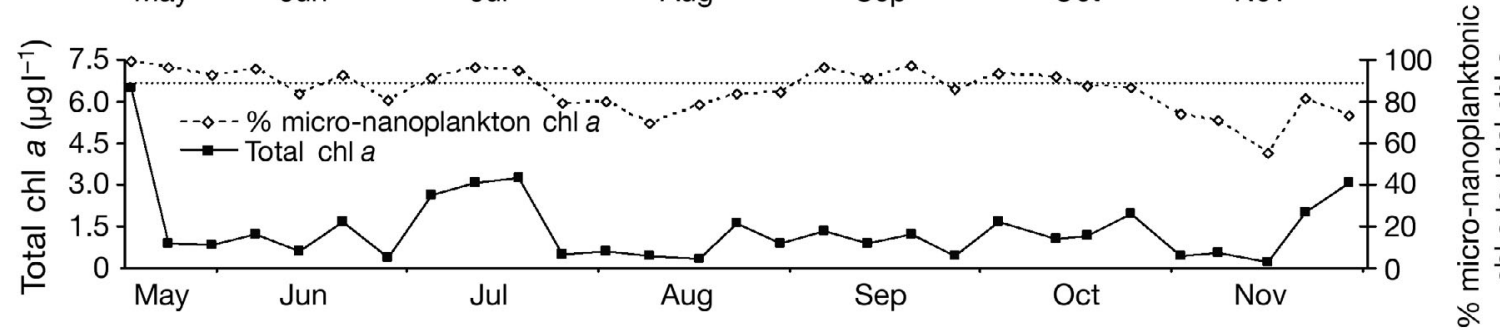

(D)

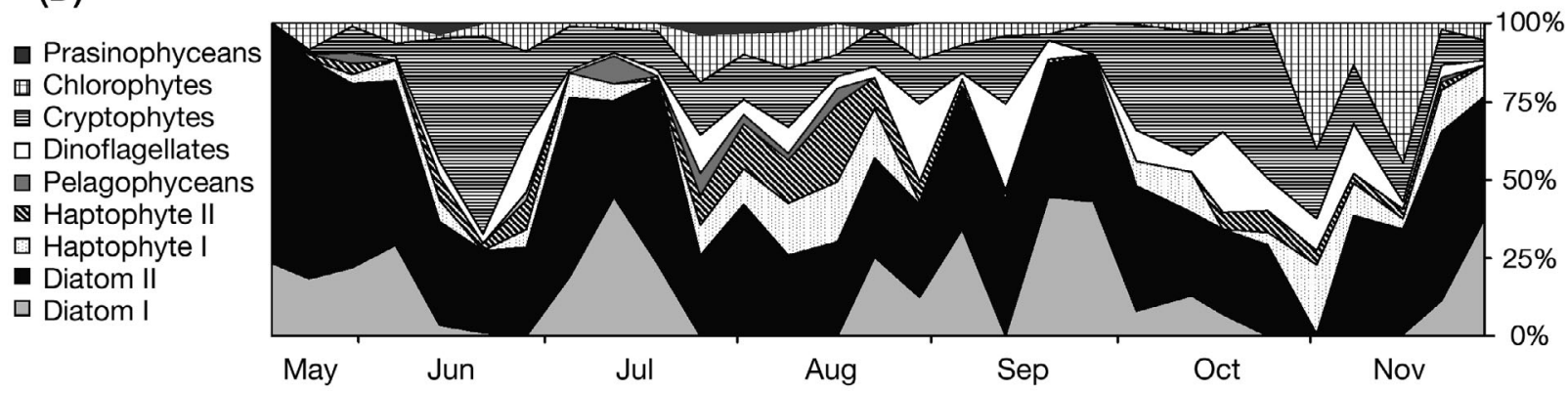

Fig. 3. Microscopic counts of (A) diatoms and dinoflagellates, (B) flagellates and haptophytes. (C) Total chl a and micronanoplankton contribution to total chl a based on size-fractionated pigment analysis. Dotted horizontal line indicates $90 \%$ micro-nanoplankton chl $a$ and $10 \%$ picoplankton chl $a$, the latter value sets a threshold over which chl $b$-containing groups dominate chl $c$-containing ones in the picoplankton. (D) Percentage of micro-nanoplanktonic chl a for different pigment groups estimated by CHEMTAX

this study (Chlorophyta, Haptophyta, Cryptophyta and Pelagophyceae). Pigment analysis also showed that chlorophytes and non-chlorophytes made similar contributions to picophytoplankton biomass $(56 \pm$ 18 and $44 \pm 18 \%$, respectively, calculated from data shown in Fig. 4C). It must be emphasized that nonchlorophytes from pigment analysis include only chl $\mathrm{C}$ containing picophytoplankters, whereas non-chlorophytes identified by FISH-TSA also include heterotrophic organisms. Prokaryotes were not included (Synechococcus-type cyanobacteria only constituted $4 \%$ of total picoplanktonic chl a according to pigment analysis).

A significant fraction $(53 \pm 29 \%)$ of picoplanktonic chlorophyte cells belonged to Mamiellales according to FISH-TSA as targeted by the specific molecular probe PRAS04 (Fig. 4A). Micromonas was by far the most abundant genus within Mamiellales (67 $\pm 27 \%$ of the Mamiellales, and $22 \pm 18 \%$ of all picoeukaryotes). Bathycoccus probes hybridized $\sim 1 \%$ of Mamiellales and no Ostreococcus cells were detected. In contrast to FISH-TSA measurements of cell abundance, pigment analysis indicated that Mamiellales accounted for only $7 \pm 7 \%$ (range, 0 to $17 \%$ ) of the chl a contributed by all chl $b$-containing picophytoplankton groups (Mamiellales, prasinophyceans and chlorophytes; time series average of data shown in Fig. 4C).

Regarding environmental variables and FISH-TSA groups, a significant positive relationship with temperature was obtained for chlorophytes $\left(\mathrm{p}<0.01 ; \mathrm{r}^{2}=\right.$ 
(A)

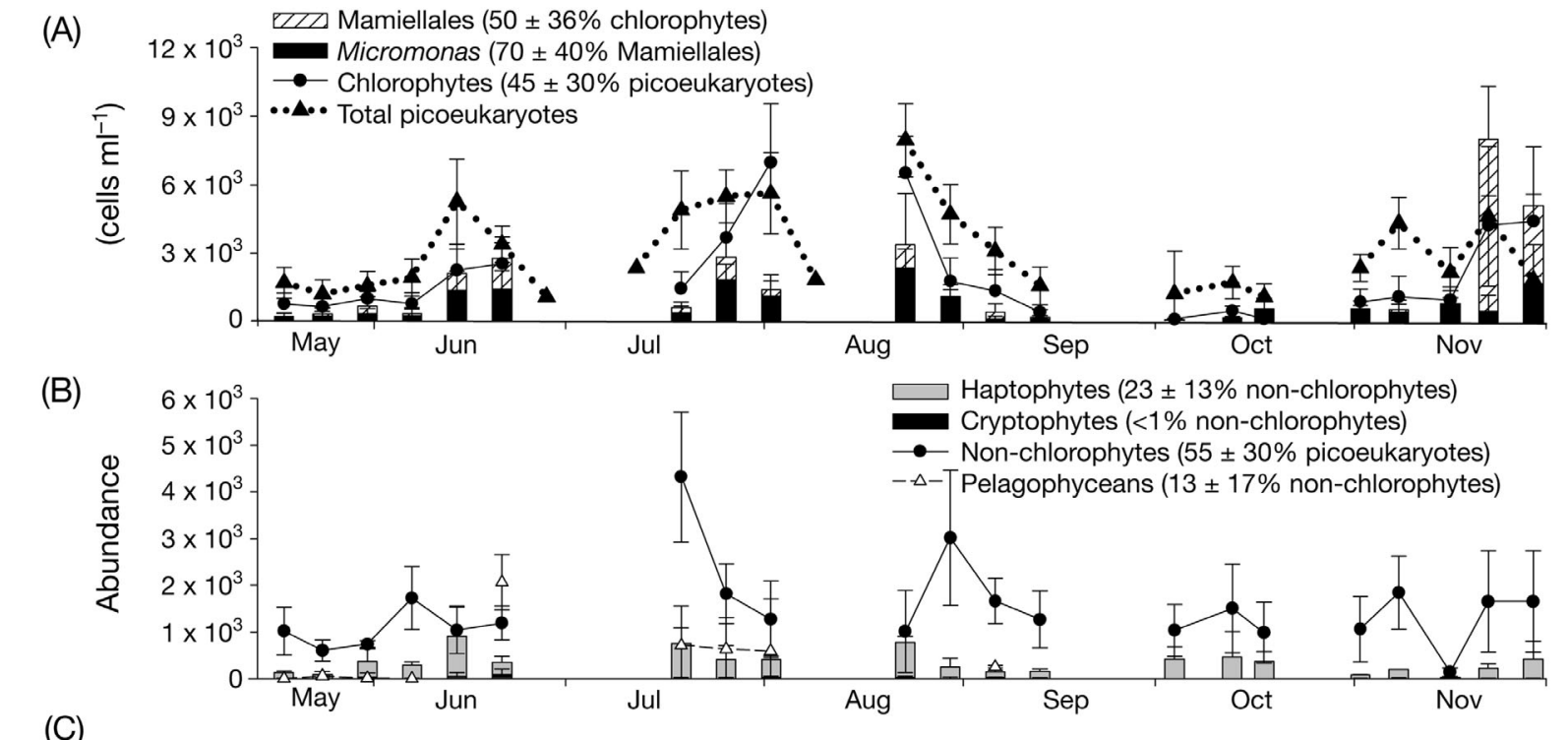

(C)
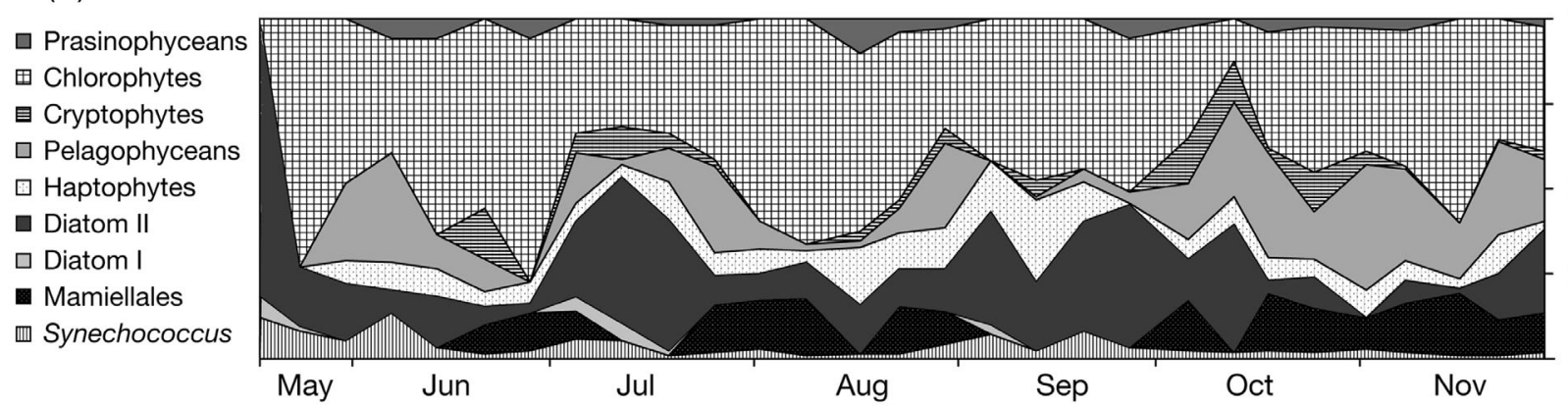

$100 \%$

Fig. 4. Abundances of picoeukaryotes groups targeted by FISH-TSA. (A) Total picoeukaryotes and chlorophytes. Mamiellales and Micromonas numbers are represented in overlaid bars to show the proportion of the latter within Mamiellales. Values in parentheses are relative percentage \pm SD of each category within the upper inmediate group. (B) Non-chlorophytes, haptophytes and cryptophytes. (C) Contribution to picoplanktonic chl a of different pigment groups estimated by CHEMTAX

$0.55 ; \mathrm{n}=18)$, Micromonas $\left(\mathrm{p}<0.05 ; \mathrm{r}^{2}=0.48 ; \mathrm{n}=18\right)$ and total picoeukaryotic counts $\left(\mathrm{p}<0.05 ; \mathrm{r}^{2}=0.49 ; \mathrm{n}=\right.$ 18). For pigment groups, chl b-containing ones showed negative relationships with salinity (chlorophytes: $\mathrm{p}<0.01 ; \mathrm{r}^{2}=-0.53 ; \mathrm{n}=18$; prasinophyceans: $\mathrm{p}<0.01 ; \mathrm{r}^{2}=-0.59 ; \mathrm{n}=18$; Mamiellales: $\mathrm{p}<0.01 ; \mathrm{r}^{2}=$ $-0.52 ; \mathrm{n}=18$ ).

Haptophytes accounted for $12 \pm 10 \%$ of total picoeukaryotes ( $25 \%$ non-chlorophytes) identified by FISH-TSA (Fig. 4B). Cryptophytes were a minor group ( $<1 \%$ total picoeukaryotic cells). Pelagophyceans, only screened until September, represented $10 \%$ on average of picoeukaryotic cells during that period. However, this average is biased ( $\mathrm{SD} \pm 18 \%$ ) due to a value of $60 \%$ on 21 June; if that is excluded, the resulting average of pelagophyceans would be $5 \%$. A major fraction $(38 \pm 21 \%)$ of non-chlorophyte cells-presumed to include both autotrophic and heterotrophic organisms - were untargeted by our probes (Fig. 4B).

The diatom I and II pigment groups were ubiquitously found in the picoplankton, contributing $22 \%$ total chl $a$ in this size class. The diatom I pigment group (chl $c_{1}$-containing) represented 10 -fold lower chl a values compared to the diatom II pigment group (Fig. 4C). The diatom II pigment group, pelagophyceans and haptophytes were the major chl $c$-containing pigment groups $(20,13$ and $8 \%$ of picoplanktonic chl $a$, respectively). In the particular samples where picoplanktonic chl $a$ represented $>10 \%$ of total chl a (dashed horizontal line in Fig. 3C), chl $b$-containing groups dominated over chl $c$-containing groups ( $65 \%$ picoplanktonic $\mathrm{chl}$ a). An identical trend was observed regarding chlorophytes and non-chlorophytes targeted by FISH-TSA.

A significant positive relationship, best fit by an exponential model, was found between the proportion of total chl $a$ in the picoplankton size fraction and $\operatorname{chl} b: \operatorname{chl} a$ ratio $\left(\mathrm{p}<0.001 ; \mathrm{r}^{2}=0.642 ; \mathrm{n}=29\right)$ (Fig. 5). From the corresponding equation we estimated that, if $100 \%$ of the chl a was contributed by picoplankton, then the chl $b: \mathrm{chl} a$ ratio would be 0.95 . Neither $\mathrm{chl} c: \mathrm{chl} a$ ratios or absolute picoplanktonic chl a were correlated with percentage of picoplankton to total chl $a$. 


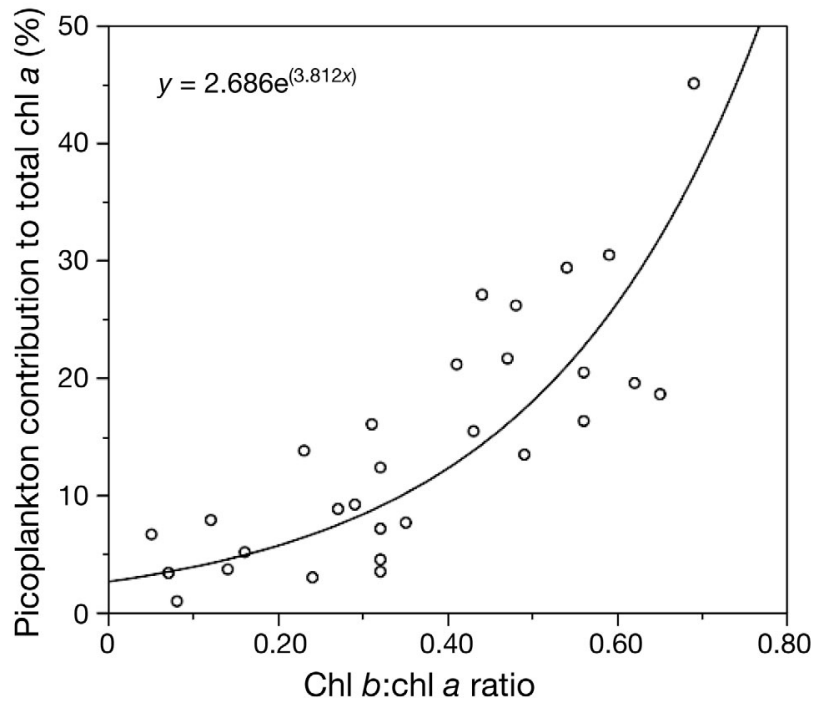

Fig. 5. Relationship (exponential model) between percentage of picoplanktonic to total $\mathrm{chl} a$, and $\mathrm{chl} b$ :chl $a$ ratios in the picoplankton $\left(\mathrm{p}<0.001 ; \mathrm{r}^{2}=0.642 ; \mathrm{n}=29\right)$

\section{DISCUSSION}

\section{Micro-nanoplankton diversity}

Many studies have underscored the differences between marker pigments and microscopic counts when reconstructing phytoplankton assemblages in the field (Havskum et al. 2004, Llewellyn et al. 2005, Rodríguez et al. 2006). They agreed on the fact that diatom biomass estimates based on pigments and cell counts are usually consistent, whereas other phytoplankton groups show significant correlations between both techniques, but are not quantitatively comparable (Havskum et al. 2004). In this sense, the dominance of the chl $C_{3}$-containing diatom II pigment group matched the high abundance accounted for by species such as Leptocylindrus danicus. As in the present study, the contribution of certain phytoplankton groups, such as small cryptophytes and haptophytes, can be overlooked in microscopic counts. We found that the relative contribution of dinoflagellates to chl a was quite low, in agreement with a previous study in the same sampling area (Rodríguez et al. 2003), and cell counts showed that peridinin-containing species were the dominant autotrophic dinoflagellates at the Ría de Pontevedra. Regarding haptophytes, inverted microscopy was not able to identify a set of dominant species. Using pigment analysis, the minor but widespread non-polar chl $C_{2}$ suggests that in addition to Phaeocystis sp. (corresponding with haptophyte I pigment group, Emiliania huxleyi as representative species; Zapata et al. 2004), the genus Chrysochromulina (identified as haptophyte II pigment group by their exclusive marker chl $C_{2}$-MGDG [14:0/14:0]; Zapata et al. 2001) would be an important component of the haptophyte population. The Chrysochromulina genus is mostly composed of small organisms $(\sim 5 \mu \mathrm{m})$ and could have easily been overlooked in microscopy.

\section{Picoplankton diversity}

During most of the last 2 decades, natural fluorescence, observed by epifluorescence microscopy or flow cytometry, and marker pigment analyses were the only quantitative techniques for large-scale investigation of picoplankton diversity (Havskum et al. 2004, Veldhuis $\&$ Kraay 2004). However, they usually lack the resolution (especially epifluorescence microscopy and flow cytometry) required for investigation at a fine taxonomic level. The recent advance within the field of biological oceanography and the progress made in quantitative (or semi-quantitative) molecular tools such as FISH, Dot-Blot and Q-PCR allow for more detailed and extensive phylogenetic surveys (Biégala et al. 2003, Not et al. 2004, Fuller et al. 2006).

Marker pigments estimated that chl $b$ - and chl $c$ containing organisms co-dominated the picoplankton at Stn P2. According to FISH-TSA, chlorophytes and non-chlorophytes contributed $\sim 50 \%$ each of total picoeukaryote cell numbers, with the non-chlorophyte category including heterotrophic cells. Although the proportion of picoheterotrophs was not determined in the present study, this component of the picoplankton community has been estimated to contribute up to $25 \%$ of the total cell numbers in several other regions (Not et al. 2005, Jürgens \& Massana in press, Worden $\&$ Not in press). Thus, picoheterotrophs could contribute to the small differences between pigment and FISH-TSA estimates of the contribution of chlorophytes versus non-chlorophytes to the picoplankton community.

The diatom-like pigment groups observed in the picoplankton size fraction in the present study might have included broken diatom cells, non-diatom picoeukaryotic heterokonts and potentially also certain haptophytes with diatom-like pigment signatures. Some haptophyte genera contain fucoxanthin as the unique accessory carotenoid (e.g. Pavlova, Isochrysis and Prymnesium; Zapata et al. 2004) while several other genera (e.g. Phaeocystis and Chrysochromulina) include isolates with fucoxanthin as a major carotenoid (Zapata et al. 2004). In the present study, the picoplanktonic haptophytes accounted for $12 \%$ of total picoeukaryotic cells (by FISH-TSA) and $7 \%$ total chl a (by pigment analysis). This is very similar to the results of Not et al. (2005) in Arctic waters (6\% contribution of haptophytes determined by FISH-TSA) whereas hap- 
tophytes were not determined in the English Channel survey (Not et al. 2004). Therefore, picohaptophytes with diatom-like pigment signatures cannot fully explain the presence of diatom pigment signatures in the picoplankton fraction. Bolidophytes, although previously reported as minor in coastal and oceanic samples (Guillou et al. 1999, Not et al. 2005, Fuller et al. 2006), would also match the diatom II pigment group. We analyzed the chl $c$ composition of 2 bolidophytes in the Roscoff Culture Collection (strains RCC 216 and 238, Bolidomonas pacifica and B. mediterranea, respectively), which unambiguously showed chl $C_{3}$ and chl $C_{2}$ as unique accessory chlorophylls. Although more and more picoplankton cultures have become available in recent years (Vaulot et al. 2004), more progress needs to be made in their pigment characterization across different algal classes (Zapata 2005). Molecular probes for various taxonomic levels of heterokonts were not available at the time of the present study, highlighting the need for more groupspecific FISH probes.

In a survey conducted in the English Channel using FISH-TSA, an average of $85 \%$ of picoeukaryotes were assigned to chlorophytes (Not et al. 2004). That study found that $78 \%$ of chlorophytes belonged to the order Mamiellales, with Micromonas pusilla alone accounting for $75 \%$ of Mamiellales (thus $45 \%$ of total picoeukaryote cells). In the present study, the Mamiellales probe targeted $\sim 55 \%$ of chlorophyte cells, confirming the importance of this prasinophyte order among 'green' picoplankton. In comparison with the English Channel survey, we detected less relative contribution of chlorophytes and less Mamiellales and M. pusilla ( $20 \%$ total picoeukaryotes). Our results better matched those obtained at the confluence of Arctic and NE Atlantic waters, where chlorophytes and M. pusilla represented 47 and $32 \%$ of picoeukaryotes, respectively (Not et al. 2005). One reason for the underestimation of Mamiellales by HPLC in comparison with FISH-TSA likely comes from the failure to detect small prasinoxanthin and uriolide amounts by extant prasinophyceans in the field. Not et al. (2005) did not detect significant levels of these carotenoids to allow prasinophyceans to be distinguished despite their relevant contribution from FISHTSA. Using HPLC, prasinoxanthin:chl $b$ ratios during the sampling period averaged $0.079 \pm 0.057$, which is far below the ratio in cultures of Mamiellales (0.140 to 0.302, calculated from Latasa et al. 2004). Uriolide, the specific marker for Mamiellales in the present study, averaged $0.026 \pm 0.025$ (uriolide:chl $b$ ) compared with 0.070 to 0.135 calculated from Latasa et al. (2004). The low ratios of these compounds could be due to $\mathrm{chl} b$ containing flagellates without prasinoxanthin and uriolide. The isolation and characterization of pigment composition under diverse physiological conditions for new Mamiellales strains, particularly of the genus Micromonas, will be crucial to improving HPLC estimates in the field. In addition, the development of concentrating procedures for pigment extracts, allowing recovery of each pigment with equivalent efficiency, would be valuable. According to Schlüter \& Møhlenberg (2003), the low prasinoxanthin:chl $b$ ratios and near-absence of lutein would indicate that chl $b$-containing groups were dominated by prasinophyceans, also including species lacking prasinoxanthin (e.g. Prasinoderma and Crustomastix stigmatica; Latasa et al. 2004). However, this still would not explain the different estimates for Mamiellales obtained by HPLC and FISH-TSA methods.

\section{Phytoplankton group succession along the time series}

Pronounced differences were observed between diversity and dynamics of the micro-nano $(>3 \mu \mathrm{m})$ and pico $(<3 \mu \mathrm{m})$ size fractions. Micro-nanophytoplankton showed patterns typical of that seen previously in the Galician Rías (Varela 1992, Tilstone et al. 2003) with strong shifts in composition following changes in hydrographic conditions. For instance, the periodic development of diatom populations during upwelling events (May, July and September) was followed by transitional periods of relaxation/stratification and downwelling (June, August and October), where remineralization processes (maxima of $\mathrm{NH}_{4}^{+}$) and increase of picophytoplankton was observed. Although clearly dominated by chl $b$-containing organisms (Mamiellales sensu FISH-TSA), seasonal changes also occurred for picophytoplankton, but variations were less distinct (Fig. 4C). No linkage between pico- and nano-micro size fractions were observed, even for taxonomic groups represented in both (e.g. cryptophytes, Figs. 3D \& 4C). Such uncoupling has also been observed in the English Channel (N. Simon pers. comm.).

In contrast to micro- and nano-phytoplankton for which taxonomic occurrence responds to classical physicochemical parameters such as light, temperature and nitrogen availability, very little is known about the factors which regulate picophytoplankton diversity. Temperature and salinity were the only variables that exhibited a significant relationship in picoplankton groups, in particular chl $b$-containing organisms. This indicates that transitional periods between upwelling conditions (with raised temperatures due to relaxation or downwelling conditions) and/or mixing with low-salinity waters in the upper layers due to water rainfall favored the development 
of picoplankton populations. The significant relationship between chl $b$ :chl a ratio and the total picoplankton contribution to chl a suggest that these groups are better adapted (among other picoplankters) to thrive under environmental conditions where larger cells diminish their populations. In addition, the $0.95 \mathrm{chl} b$ :chl a ratio corresponding to $100 \%$ picoplankton to total chl $a$, being only extrapolated data, is meaningful as it would fall within the usual range measured for prasinophyceans (Latasa et al. 2004).

We could not identify any significant trends in the case of nutrients. However, with respect to bottom-up control, one can hypothesize different resource utilizations according to the size of organisms (e.g. chlorophytes, cryptophytes and haptophytes) and the influence of environmental parameters. This statement holds for broad taxonomic groups, awaiting finer taxonomic identification and physiological studies of picophytoplankton organisms involved.

Acknowledgements. We thank the crew of RV 'José María Navaz' for sample collection and all the staff in the Department of Oceanographic Conditions and Phytoplankton at INTECMAR for light microscopy and nutrient data. We also thank F. Le Gall (Station Biologique de Roscoff, UPMCCNRS) for providing Bolidomonas cultures and D. Vaulot for laboratory facilities and helpful comments on the manuscript. We are also grateful to P. von Dassow for comments and improvement of the English. F.R. was supported by a postdoctoral fellowship from Caixanova Foundation.

\section{LITERATURE CITED}

Amann RI, Zarda B, Stahl DA, Schleifer KH (1992) Identification of individual prokaryotic cells by using enzyme labelled rRNA-targeted oligonucleotide probes. Appl Environ Microbiol 58:3007-3011

Biégala IC, Not F, Vaulot D, Simon N (2003) Quantitative assessment of picoeukaryotes in the natural environment using taxon-specific oligonucleotide probes in association with tyramide signal amplification-fluorescent in situ hybridization and flow cytometry. Appl Environ Microbiol 69:5519-5529

Doval MD, Nogueira E, Pérez FF (1998) Spatio-temporal variability of the thermohaline and biogeochemical properties and dissolved organic carbon in a coastal embayment affected by upwelling: the Ría de Vigo (NW Spain). J Mar Syst 14:135-150

Figueiras FG, Niell FX (1987) Distribución estacional y espacial del fitoplancton en la ría de Pontevedra (NO de España). Invest Pesq 51:293-320

Figueiras FG, Labarta U, Fernández Reiriz MJ (2002) Coastal upwelling, primary production and mussel growth in the Rías Baixas of Galicia. Hydrobiologia 484:121-131

Fuller NJ, Campbell C, Allen DJ, Pitt FD, Zwirglmaier K, Le Gall F, Vaulot D, Scanlan DJ (2006) Analysis of photosynthetic picoeukaryotic diversity at open ocean sites in the Arabian Sea using a PCR biased towards marine algal plastids. Aquat Microb Ecol 43:79-93

Giovannoni SJ, Delong EF, Olsen GJ, Pace NR (1988) Phylo- genetic group-specific oligonucleotide probes for identification of single microbial cells. J Bacteriol 170:720-726

Guillou L, Moon-van der Staay SY, Claustre H, Partensky F, Vaulot D (1999) Diversity and abundance of Bolidophyceae (Heterokonta) in oceanic waters. Appl Environ Microbiol 65:4528-4536

Havskum H, Schlüter L, Scharek R, Berdalet E, Jacquet S (2004) Routine quantification of phytoplankton groups microscopy or pigment analyses? Mar Ecol Prog Ser 273: $31-42$

Jeffrey SW, Mantoura RFC, Bjørnland T (1997) Data for the identification of 47 key phytoplankton pigments. In: Jeffrey SW, Mantoura RFC, Wright SW (eds) Phytoplankton pigments in oceanography: guidelines to modern methods. UNESCO, Paris, p 449-559

Jürgens $\mathrm{K}$, Massana $\mathrm{R}$ (in press) Protist grazing on marine bacterioplankton. In: Kirchman DL (ed) Microbial ecology of the oceans, 2nd edn. Wiley-Liss, New York

Latasa M, Van Lenning K, Garrido JL, Scharek R, Estrada M, Rodríguez F, Zapata M (2001) Losses of chlorophylls and carotenoids in aqueous acetone and methanol extracts prepared for RP-HPLC analysis of pigments. Chromatographia 53:385-391

Latasa M, Scharek R, Le Gall F, Guillou L (2004) Pigment suites and taxonomic groups in Prasinophyceae. J Phycol 40:1149-1155

Lindahl O (1986) A dividable hose for phytoplankton sampling, Vol 26. ICES, Center of Environmental Science (Annex 3), Hirtshals

Llewellyn CA, Fishwick JR, Blackford JC (2005) Phytoplankton community assemblage in the English Channel: a comparison using chl a derived from HPLC-CHEMTAX and carbon derived from microscopy cell counts. J Plankton Res 27:103-119

Lorenzo LM, Arbones B, Tilstone GH, Figueiras FG (2005) Across-shelf variability of phytoplankton composition, photosynthetic parameters and primary production in the NW Iberian upwelling system. J Mar Syst 54:157-173

Mackey MD, Mackey DJ, Higgins HW, Wright SW (1996) CHEMTAX - a program for estimating class abundance from chemical markers: application to HPLC measurements of phytoplankton. Mar Ecol Prog Ser 144:265-283

Mariño J, Maneiro J, Blanco J (1998) The harmful algae monitoring programme of Galicia: good value for money. In: Reguera B, Blanco J, Fernández ML, Wyatt T (eds) Harmful algae. Xunta de Galicia and Intergovernmental Oceanographic Commission of UNESCO, Santiago de Compostela, p 229-232

Not F, Simon N, Biegala IC, Vaulot D (2002) Application of fluorescent in situ hybridization coupled with tyramide signal amplification (FISH-TSA) to assess eukaryotic picoplankton composition. Aquat Microb Ecol 28: 157-166

Not F, Latasa M, Marie D, Cariou T, Vaulot D, Simon N (2004) A single species Micromonas pusilla (Prasinophyceae), dominates the eukaryotic picoplankton in the Western English Channel. Appl Environ Microbiol 70:4064-4072

Not F, Massana R, Latasa M, Marie D and 5 others (2005) Late summer community composition and abundance of photosynthetic picoeukaryotes in Norwegian and Barents seas. Limnol Oceanogr 50:1677-1686

Rodríguez F, Pazos Y, Maneiro J, Zapata M (2003) Temporal variation in phytoplankton assemblages and pigment composition in a fixed station of the Ría of Pontevedra (NW Spain). Estuar Coast Shelf Sci 58:499-515

Rodríguez F, Garrido JL, Crespo BG, Arbones B, Figueiras FG (2006) Size-fractionated phytoplankton pigment groups in 
the NW Iberian upwelling system: impact of the Iberian Poleward Current. Mar Ecol Prog Ser 323:59-73

Schlüter L, Møhlenberg F (2003) Detecting presence of phytoplankton groups with non-specific pigment signatures. J Appl Phycol 15:465-476

Simon N, Lebot N, Marie D, Parténsky F, Vaulot D (1995) Fluorescent in situ hybridization with rRNA-targeted oligonucleotide probes to identify small phytoplankton by flow cytometry. Appl Environ Microbiol 61:2506-2513

Simon N, Campbell L, Ornolfsdöttir E, Groben R, Guillou L, Lange M, Medlin LK (2000) Oligonucleotide probes for the identification of three algal groups by dot blot and fluorescent whole-cell hybridization. J Eukaryot Microbiol 47:76-84

Tilstone GH, Figueiras FG, Lorenzo LM, Arbones B (2003) Phytoplankton composition, photosynthesis and primary production during different hydrographic conditions at the Northwest Iberian upwelling system. Mar Ecol Prog Ser 252:89-104

Urdea MS, Warner BD, Running JA, Stempien M, Clyne J, Horn T (1988) A comparison of non-radioisotopic hybridization assay methods using fluorescent, chemiluminescent, and enzyme labelled oligodeoxyribonucleotide probes. Nucleic Acids Res 16:4937-4956

Utermöhl H (1958) Zur Vervollkommnung der quantitativen Phytoplankton Methodik. Mitt Int Verein Theor Angew Limnol 9:1-38

Varela M (1992) Upwelling and phytoplankton ecology in Galician (NW Spain) rías and shelf waters. Bol Inst Esp Oceanogr 8:57-74

Vaulot D, Le Gall F, Marie D, Guillou L, Parténsky F (2004) The Roscoff Culture Collection (RCC): a collection dedi-

Editorial responsibility: Willliam Li,

Dartmouth, Nova Scotia, Canada cated to marine picoplankton. Nova Hedwigia 79:49-70

Veldhuis MJW, Kraay GW (2004) Phytoplankton in the subtropical Atlantic Ocean: towards a better assessment of biomass and composition. Deep-Sea Res 51:507-530

Wawrik B, Paul JH, Campbell L, Griffin D, Houchin L, Fuentes-Ortega A, Muller-Karger F (2003) Vertical structure of the phytoplankton community associated with a coastal plume in the Gulf of Mexico. Mar Ecol Prog Ser 251:87-101

Worden AZ, Not F (in press) Ecology and diversity of picoeukaryotes In: Kirchman DL (ed) Microbial ecology of the oceans, 2nd edn. Wiley-Liss, New York

Zapata M (2005) Recent advances in pigment analysis as applied to picophytoplankton. Vie Milieu 55:233-248

Zapata M, Garrido JL (1991) Influence of injection conditions in reversed phase high-performance liquid chromatography of chlorophylls and carotenoids. Chromatographia 31: 589-594

Zapata M, Rodríguez F, Garrido JL (2000) Separation of chlorophylls and carotenoids from marine phytoplankton: a new HPLC method using a reversed phase $\mathrm{C}_{8}$ column and pyridine-containing mobile phases. Mar Ecol Prog Ser 195:29-45

Zapata M, Edvardsen B, Rodríguez F, Maestro MA, Garrido JL (2001) Chlorophyll $C_{2}$ monogalactosyldiacylglyceride ester (chl $C_{2}$-MGDG) a marker pigment for Chrysochromulina polylepis species (Haptophyta). Mar Ecol Prog Ser 219:85-98

Zapata M, Jeffrey SW, Rodríguez F, Clementson L, Garrido JL, Wright SW (2004) Pigment variability in 37 species (65 strains) of Haptophyta: implications for phylogeny and oceanography. Mar Ecol Prog Ser 270:83-102

Submitted: June 3, 2007; Accepted: September 12, 2007

Proofs received from author(s): November 6, 2007 